\title{
Diagnosis and clinic-pathological findings of influenza virus infection in Brazilian pigs ${ }^{1}$
}

\author{
Daniela S. Rajão ${ }^{2 *}$, Diego H. Couto ${ }^{3}$, Marcela R. Gasparini ${ }^{2}$, Adrienny T.R. Costa ${ }^{4}$, \\ Jenner K.P. Reis ${ }^{2}$, Zélia I.P. Lobato ${ }^{2}$, Roberto M.C. Guedes ${ }^{3}$ and Rômulo C. Leite ${ }^{2}$
}

\begin{abstract}
Rajão D.S., Couto D.H., Gasparini M.R., Costa A.T.R., Reis J.K.P., Lobato Z.I.P., Guedes R.M.C. \& Leite R.C. 2013. Diagnosis and clinic-pathological findings of influenza virus infection in Brazilian pigs. PesquisaVeterináriaBrasileira 33(1):30-36.Departamento de Medicina Veterinária Preventiva, Escola de Veterinária, Universidade Federal de Minas Gerais, Av. Presidente Antônio Carlos 6627, Cx. Postal 567, Belo Horizonte, MG 31270901, Brazil. E-mail: rajao.ds@gmail.com

Influenza $A$ virus (IAV) is a respiratory pathogen of pigs and is associated with the porcine respiratory disease complex (PRDC), along with other respiratory infectious agents. The aim of this study was to diagnose and to perform a clinic-pathological characterization of influenza virus infection in Brazilian pigs. Lung samples from 86 pigs in 37 farrow-to-finish and two farrow-to-feeder operations located in the States of Minas Gerais, São Paulo, Paraná, Rio Grande do Sul, Santa Catarina, and Mato Grosso were studied. Virus detection was performed by virus isolation and quantitative real time reverse-transcription PCR (qRT-PCR). Pathologic examination and immunohistochemistry (IHC) were performed in 60 lung formalin-fixed paraffin-embedded tissue fragments. Affected animals showed coughing, sneezing, nasal discharge, hyperthermia, inactivity, apathy, anorexia, weight loss and growth delay, which lasted for five to 10 days. Influenza virus was isolated from 31 (36.0\%) lung samples and 36 (41.9\%) were positive for qRT-PCR. Thirty-eight (63.3\%) lung samples were positive by IHC and the most frequent microscopic lesion observed was inflammatory infiltrate in the alveoli, bronchiole, or bronchi wall or lumen (76.7\%). These results indicate that influenza virus is circulating and causing disease in pigs in several Brazilian states.
\end{abstract}

INDEX TERMS: Influenza, pig, lesion, pathology, clinical signs.

\begin{abstract}
RESUMO.- [Diagnóstico, achados clínicos e patológicos da infecção pelo vírus influenza em suínos no Brasil.] 0 vírus influenza A (IAV) é um patógeno respiratório comum de suínos e faz parte do complexo de doenças respiratórias do suíno (PRDC) junto com outros agentes infecciosos. 0 objetivo deste estudo foi diagnosticar e realizar a caracterização clínica e patológica de casos/surtos de influenza em suínos brasileiros. Foram utilizadas amostras de teci-
\end{abstract}

\footnotetext{
${ }^{1}$ Received on July 17, 2012.

Accepted for publication on October 19, 2012.

${ }^{2}$ Departamento de Medicina Veterinária Preventiva, Escola de Veterinária, Universidade Federal de Minas Gerais (UFMG), Av. Presidente Antônio Carlos 6627, Cx. Postal 567, Belo Horizonte, MG 31270-901, Brazil. *Corresponding author: rajao.ds@gmail.com

${ }^{3}$ Departamento de Clínica e Cirurgia Veterinárias, Escola de Veterinária, UFMG, Cx. Postal 567, Belo Horizonte, MG 31270-901.

${ }^{4}$ Instituto de Pesquisas Veterinárias Especializadas Ltda (IPEVE), Rua Esmeralda 786, Belo Horizonte, MG 30411-191.
}

do pulmonar de 86 suínos de 37 granjas de ciclo completo e duas unidades produtoras de leitões localizadas em Minas Gerais, São Paulo, Paraná, Rio Grande do Sul, Santa Catarina e Mato Grosso. A detecção viral em fragmentos pulmonares frescos foi realizada através do isolamento viral e da transcrição reversa-PCR em tempo real quantitativa (qRT-PCR). Exame patológico e imuno-histoquímica (IHQ) foram realizados em 60 amostras de pulmão fixadas em formalina $10 \%$ e embebidas em parafina. As amostras eram de animais apresentando tosse, espirros, secreção nasal, hipertermia, prostração, apatia, anorexia, perda de peso e ganho de peso reduzido, com duração entre cinco e 10 dias. 0 vírus influenza foi isolado de $31(36,0 \%)$ amostras e $36(41,9 \%)$ foram positivas na qRT-PCR. Na IHQ 38 $(63,3 \%)$ amostras foram positivas e a lesão mais frequentemente observada foi a presença de infiltrado inflamatório na parede e lúmen de vias aéreas (76,7\%). Estes resultados indicam que o vírus influenza está circulando e causando 
lesões e doença respiratória em suínos de diversos Estados do Brasil.

TERMOS DE INDEXAÇÃO: Influenza, suíno, lesão, patologia, sinais clínicos.

\section{INTRODUCTION}

The first clinical description of swine influenza occurred in 1918, concurrently to the Spanish Flu occurrence in the human population (Koen 1919, Webster 1992). Since then, influenza A viruses (IAV) have been associated with the porcine respiratory disease complex (PRDC), along with other pathogens such Mycoplasma hyopneumoniae, Actinobacillus pleuropneumoniae, Pasteurella multocida, porcine reproductive and respiratory syndrome virus (PRRSV), and porcine circovirus type 2 (PCV2) (Thacker et al. 2001, Vincent et al. 2008).

Influenza A virus is an enveloped Orthomyxo virus with a segmented RNA genome (Palese \& Shaw 2007). Three antigenic distinct IAV subtypes circulate in pigs worldwide - H1N1, H3N2, and H1N2-, and they are endemic and frequently isolated in the United States, Europe, and Asia (Van Reeth 2007). Swine influenza is an acute respiratory disease, in which numerous factors may interfere with the severity, including host immune status, viral strain, and secondary infections (Vincent et al. 2008). Clinical signs of influenza in pigs are similar to those observed in humans, with fever, respiratory distress, coughing, nasal secretion, conjunctivitis, inactivity, and decreased food intake (Alexander \& Brown 2000, Richt et al. 2003). Dark-red consolidation areas, with predominately cranio-ventral location, characterize lungs lesions in influenza infection. Most common microscopic lesions are necrosis of bronchiolar epithelial cells with cellular debris, proteinaceous fluid, and leukocytes in the airway lumen. Necrosis is often accompanied by peribronchiolar lymphocytic infiltration and interstitial pneumonia (Vincent et al. 2008).

Influenza virus was first detected in Brazilian pigs in 1978 (Cunha et al. 1978), and previous serological studies have demonstrated it is highly disseminated in various states (Brentano et al. 2002, Mancini et al. 2006, Caron et al. 2010, Rajão et al. 2012). However, only few viruses have been isolated (Mancini et al. 2006, Schaefer et al. 2011), and the disease has not been characterized in Brazil. The goal of this work was to diagnose and perform a clinical and pathological description of influenza virus infection occurring in pigs in six Brazilian states.

\section{MATERIALS AND METHODS}

\section{Clinical samples}

Lung samples from 86 routine diagnostic cases received between July 2009 and August 2010 from a private diagnostic laboratory were used. Samples were collected during respiratory disease outbreaks in 37 farrow-to-finish and two farrow-to-feeder operations with all-in-all-out system, with no IAV vaccination history. Herds were located in Minas Gerais (24), São Paulo (2), Paraná (1), Rio Grande do Sul (4), Santa Catarina (1), and Mato Grosso (7) states in Brazil. Clinical data were obtained from herd owners and veterinarians. Lung sections were fixed in $10 \%$ buffered formalin or refrigerated and processed in 48 hours. Unfixed sections were homogenized in minimal essential medium (MEM) containing antibiotics $(200 \mathrm{U} / \mathrm{mL}$ penicillin, $200 \mu \mathrm{g} / \mathrm{mL}$ streptomycin, and $1.25 \mu \mathrm{g} / \mathrm{mL}$ amphotericin B). Viral detection in the lung fragments was performed by viral isolation, quantitative real time reversetranscription PCR (qRT-PCR), and immunohistochemistry (IHC). This study was performed following the requirements for the Ethics Committee of Universidade Federal de Minas Gerais.

\section{Virus detection}

For virus isolation, $0.2 \mathrm{~mL}$ of the $10 \%$ lung homogenate was placed on confluent Madin-Darby canine kidney (MDCK) cells in 24-well plates and incubated at $37^{\circ} \mathrm{C}$ and $5 \% \mathrm{CO} 2$ for $60 \mathrm{~min}$. After $1 \mathrm{~h}$ incubation the sample was removed and $0.3 \mathrm{~mL}$ serum-free MEM supplemented with $2 \mu \mathrm{g} / \mathrm{ml}$ TPCK (tolylsulfonylphenylalanylchloromethyl ketone) - treated trypsin (Merck, Darmstadt, Germany) was added (WHO 2002). The plates were incubated for up to six days and checked daily for cytopathic effect (CPE). If evidence of CPE was observed or after 6 days, supernatants media were collected and pools of the sample were tested for HA activity against $0.5 \%$ rooster red blood cell (RBC) suspension, as previously described (Killian 2008). If the HA test was negative, the samples were re-passed in MDCK cells.

Ten-fold serial dilutions of the viral isolation supernatants were made in serum-free MEM with TPCK trypsin and antibiotics and inoculated onto MDCK cells in 96-well plates. Plates were evaluated for CPE daily. After $48 \mathrm{~h}$ incubation, cells were fixed with $4 \%$ phosphate-buffered formalin and stained with anti-influenza A nucleoprotein monoclonal antibody (Millipore, Billerica, MA, USA). Virus TCID50 titer was calculated by the method of Reed and Muench (Reed \&Muench 1938).

\section{RNA extraction and Reverse Transcription}

Viral RNA extraction was carried out from $140 \mu \mathrm{L}$ cell culture-grown virus isolates using QIAamp viral RNA mini kit (QIAGEN Inc., Valencia, CA, USA), according to the manufacturer's specifications. Ten microliters of RNA were transcribed to cDNA at $42^{\circ} \mathrm{C}$ for 60 min using $0.2 \mu \mathrm{mol} / \mathrm{L}$ of Uni12 primer (5'-AGCAAAAGCAGG-3'; Hoffmann et al. 2001), $5 \mu \mathrm{L}$ of $5 \mathrm{x}$ reaction buffer, $100 \mathrm{U}$ of M-MLV reverse transcriptase (Promega, Madison, WI, USA), 0.8mmol/L of each dNTP, $25 \mathrm{U}$ of RNasinribonuclease inhibitor, and water to a final volume of $25 \mu \mathrm{L}$.

\section{Standard curve for DNA absolute quantification}

To construct the standard curve for the qRT-PCR, a fragment of 106bp of A/swine/Iowa/15/1930 (H1N1) was amplified using primers forward 5'-GACCRATCCTGTCACCTCTGAC-3'and reverse5'-AGGGCATTYTGGACAAAKCGTCTA-3' for the influenza A matrix (M) gene (WHO 2009). The RT-PCR product was cloned into pGEM®-T easy vector system (Promega, Madison, WI, USA), then transformed in Escherichia coli XL10 (Invitrogen, Carlsbad, CA, USA). Plasmid DNA was purified using miniprep protocol (Saunders \& Burke 1990) and quantified by spectrophotometric analysis. Plasmid was linearized using PstI restriction enzyme (Invitrogen, Carlsbad, CA, USA), followed by agarose gel electrophoresis. The number of DNA copies was estimated after quantification (Whelan et al. 2003) and ten fold dilutions were prepared in sterile water, consisting of $10^{0}$ to $10^{9}$ copies DNA $\mu \mathrm{L}^{-1}$ of template.

\section{Quantitative real time RT-PCR}

For qRT-PCR, amplification was performed in a 7500 Real-Time PCR System (Applied Biosystems, Foster City, CA, USA) with TaqMan® Universal PCR Master Mix (Applied Biosystems), using primers/probe set for the $\mathrm{M}$ gene of the influenza A virus as previously described (WHO 2009). Each complementary DNA sample was amplified in duplicates and the standard DNA in triplicates. 
Table 1. Description of the herds in which the study was performed: production system, location, clinical signs and age of affected animals

\begin{tabular}{|c|c|c|c|c|}
\hline Herd & $\begin{array}{l}\text { rodu } \\
\text { tion }\end{array}$ & & Clinical signs & $\begin{array}{c}\text { Age } \\
\text { (days/category) }\end{array}$ \\
\hline 1 & $\mathrm{Fi}$ & MG & Coughing $35 / \mathrm{NR}$ & \\
\hline 2 & $\mathrm{Fi}$ & MG & Coughing and nasal discharge & $60 / \mathrm{NR}$ \\
\hline 3 & $\mathrm{Fi}$ & MT & Coughing and hyperthermia & $29 / N R$ \\
\hline 4 & $\mathrm{Fi}$ & MT & $\begin{array}{l}\text { Coughing, sneezing, nasal dis- } \\
\text { charge, and diarrhea }\end{array}$ & 68-120/NR-FR \\
\hline 5 & $\mathrm{Fi}$ & MG & $\begin{array}{l}\text { Coughing, sneezing, nasal dis- } \\
\text { charge, and diarrhea }\end{array}$ & $60 / \mathrm{NR}$ \\
\hline 6 & $\mathrm{Fi}$ & MG & Coughing & $70 / \mathrm{NR}$ \\
\hline 7 & $\mathrm{Fi}$ & MG & $\begin{array}{l}\text { Severe coughing, hyperther- } \\
\text { mia, weight loss, increased } \\
\text { mortality, increased abortion }\end{array}$ & $50-100 /$ NR-GR \\
\hline 8 & $\mathrm{Fe}$ & RS & $\begin{array}{l}\text { Coughing, diarrhea, and incre- } \\
\text { ased mortality }\end{array}$ & $40-140 /$ NR-FR \\
\hline 9 & $\mathrm{Fe}$ & RS & Coughing, sneezing, and wasting & $30 / \mathrm{NR}$ \\
\hline 10 & $\mathrm{Fi}$ & MG & $\begin{array}{l}\text { Coughing, sneezing, nasal dis- } \\
\text { charge, wasting, weight loss }\end{array}$ & $70 / \mathrm{NR}$ \\
\hline 11 & $\mathrm{Fi}$ & MT & $\begin{array}{l}\text { Severe coughing, sneezing, } \\
\text { dyspnea, anorexia }\end{array}$ & $50 / \mathrm{NR}$ \\
\hline 12 & $\mathrm{Fi}$ & MG & $\begin{array}{l}\text { Coughing, inactivity, and } \\
\text { apathy }\end{array}$ & $50 / \mathrm{NR}$ \\
\hline 13 & $\mathrm{Fi}$ & SP & Coughing and sneezing & $34-60 / N R$ \\
\hline 14 & $\mathrm{Fi}$ & MT & Coughing and sneezing & $65-100 / N R-G R$ \\
\hline 15 & $\mathrm{Fi}$ & SP & Coughing and nasal discharge & $35-56 / N R$ \\
\hline 16 & $\mathrm{Fi}$ & MG & $\begin{array}{l}\text { Coughing, sneezing, and nasal } \\
\text { discharge }\end{array}$ & 30-135/NR-FR \\
\hline 17 & $\mathrm{Fi}$ & MG & Coughing and hyperthermia & 29-150/NR-FR \\
\hline 18 & $\mathrm{Fi}$ & MG & Coughing and diarrhea & 70-120/NR-FR \\
\hline 19 & $\mathrm{Fi}$ & MG & Coughing and hyperthermia & $45 / N R$ \\
\hline 20 & $\mathrm{Fi}$ & MG & Coughing $42 / \mathrm{NR}$ & \\
\hline 21 & $\mathrm{Fi}$ & MG & Coughing $53 / \mathrm{NR}$ & \\
\hline 22 & $\mathrm{Fi}$ & MT & $\begin{array}{l}\text { Coughing and increased mor- } \\
\text { tality }\end{array}$ & $35-100 / N R-G R$ \\
\hline 23 & $\mathrm{Fi}$ & MG & $\begin{array}{l}\text { Coughing, diarrhea, anorexia, } \\
\text { and weight loss }\end{array}$ & $52 / \mathrm{NR}$ \\
\hline 24 & $\mathrm{Fi}$ & MG & Coughing and dyspnea & $52 / \mathrm{NR}$ \\
\hline 25 & $\mathrm{Fi}$ & MG & Coughing $70 / \mathrm{NR}$ & \\
\hline 26 & $\mathrm{Fi}$ & RS & Coughing and hyperthermia & $29-50 / N R$ \\
\hline 27 & $\mathrm{Fi}$ & MG & Coughing $50 / \mathrm{NR}$ & \\
\hline 28 & $\mathrm{Fi}$ & MG & $\begin{array}{l}\text { Coughing, sneezing, and inac- } \\
\text { tivity }\end{array}$ & $60 / \mathrm{NR}$ \\
\hline 29 & $\mathrm{Fi}$ & MG & Mild coughing70/NR & \\
\hline 30 & $\mathrm{Fi}$ & MG & Coughing35-90/NR-GR & \\
\hline 31 & $\mathrm{Fi}$ & MG & $\begin{array}{l}\text { Severe coughing, nasal dis- } \\
\text { charge, and decay in growth }\end{array}$ & $45 / N R$ \\
\hline 32 & $\mathrm{Fi}$ & PR & $\begin{array}{l}\text { Coughing, sneezing, nasal dis- } \\
\text { charge, and decay in growth }\end{array}$ & $51 / N R$ \\
\hline 33 & $\mathrm{Fi}$ & MG & Coughing50-120/NR-FR & \\
\hline 34 & $\mathrm{Fi}$ & MT & Coughing $55 / \mathrm{NR}$ & \\
\hline 35 & $\mathrm{Fi}$ & RS & $\begin{array}{l}\text { Severe coughing, nasal dis- } \\
\text { charge, and hyperthermia }\end{array}$ & 70-90/NR-GR \\
\hline 36 & $\mathrm{Fi}$ & $\mathrm{SC}$ & $\begin{array}{l}\text { Abdominal breathing, coughing, } \\
\text { decay in growth, and incre ased } \\
\text { mortality }\end{array}$ & $60 / \mathrm{NR}$ \\
\hline 37 & $\mathrm{Fi}$ & MT & Coughing35-100/NR-GR & \\
\hline 38 & $\mathrm{Fi}$ & MG & Coughing30-105/NR-GR & \\
\hline 39 & $\mathrm{Fi}$ & MG & Coughing and sneezing & 70/NR \\
\hline
\end{tabular}

$\overline{\mathrm{Fi}}$ = Farrow-to-finish; $\mathrm{Fe}=$ Farrow-to-feeder; $\mathrm{MG}=$ Minas Gerais; $\mathrm{MT}=$ Mato Grosso; SP = São Paulo; RS = Rio Grande do Sul; PR = Paraná; SC = Santa Catarina; NR = nursery; GR = grower; FR = finisher.
Briefly, $2 \mu \mathrm{L}$ of cDNA was amplified in a $20 \mu \mathrm{L}$ reaction containing $10 \mu \mathrm{L}$ of TaqMan $2 \mathrm{X}$ Universal PCR Master Mix, $0.8 \mu \mathrm{M}$ of primers $\mathrm{M}$-For and M-Rev, $0.2 \mu \mathrm{M}$ of M-probe, and ultrapure nuclease-free water to the final volume. Thermal cycling conditions were initial incubation at $50^{\circ} \mathrm{C}$ for $2 \mathrm{~min}$, denaturation at $95^{\circ} \mathrm{C}$ for $10 \mathrm{~min}$, followed by 45 cycles of denaturation at $95^{\circ} \mathrm{C}$ for $15 \mathrm{~s}$ and annealing at $60^{\circ} \mathrm{C}$ for $1 \mathrm{~min}$. Fluorescent signal was registered during annealing step. Ten-fold serially diluted positive viral DNA control sample were used as calibrators in each run. Results represent the average data of the duplicates for each sample.

\section{Pathology}

Formalin-fixed lung tissue samples from 60 pigs were used for histopathologic examination and immunohistochemistry using Universal $\mathrm{LSAB}^{\mathrm{TM}}+/ \mathrm{HRP}$ Kit (Dako, Glostrup, Denmark). Tissues were routinely processed and stained with hematoxylin and eosin (Luna 1968).

Four-micrometer-thick tissue sections were deparaffinized in xylene, rehydrated through decreasing concentrations of ethanol. Endogenous peroxidases activity was inactivated with 3\% hydrogen peroxide immersion for $30 \mathrm{~min}$, followed by enzyme digestion with $0.05 \%$ proteinase $\mathrm{K}$ for $5 \mathrm{~min}$ at $37^{\circ} \mathrm{C}$. Slides were then incubated with $2.5 \%$ powder skim milk for 30 minutes at room temperature. The slides were incubated with mouse anti-influenza A nucleoprotein monoclonal antibody (Millipore, Billerica, MA, USA) for $45 \mathrm{~min}$ at $37^{\circ} \mathrm{C}$, followed by incubation at room temperature for 30 minutes with biotinylated anti-mouse antibody and for $25 \mathrm{~min}$ with horseradish peroxidase-conjugated streptavidin. Sections were then revealed with AEC (3-Amino-9-ethylcarbazole), counterstained with hematoxylin and mounted using aqueous mounting medium.

Samples were considered positive if they showed red staining in respiratory epithelial cells cytoplasm or nucleus. Staining intensity and distribution was scored from I to III, as mild focal, moderate multifocal, and intense multifocal, respectively. A single pathologist scored all slides.

\section{Statistical analysis}

Data were treated using Excel 2011 (Microsoft Corporation, USA) and 95\% confidence intervals (95\% CI) were calculated for positive result frequencies in the assays used.

\section{RESULTS}

\section{Clinical findings}

Description of the clinical signs observed in the tested herds is shown in Table 1. Clinical signs in all herds lasted five to 10 days. Fifty lung samples were tested during routine diagnostic screening for the infection by other respiratory pathogens, including Mycoplasma hyopneumoniae, $P$ asteurellamultocida, Bordetella bronchiseptica, Haemophilu sparasuis, Streptococcus suis, and PCV2 (data not shown). Samples were tested according to clinical signs for differential diagnosis, but not all were tested for all pathogens, and some were tested for more than one. Positive cases for $M$. hyopneumoniae (4 samples), P. multocida (18), B. bronchiseptica(7), H. parasuis(12), S. suis (11), and PCV2 (23) were detected. Co-infection of IAV with one or more pathogens was found in 32 samples.

\section{Virus detection}

Thirty samples (34.9\%; 95\% CI: 24.83-44.97\%) produced cytopathic effect (CPE) in inoculated cells. Two samples 
produced CPE only after the second passage. One sample did not produce CPE, but presented positive hemagglutination, and was considered positive. Therefore, 31 samples were positive for virus (Table 2). Bacterial growth was not observed in any of the supernatants (data not shown). Virus titers for isolates ranged from $10^{2.25}$ to $10^{6.75} \mathrm{TCID}_{50} / \mathrm{mL}$, and the mean titer was $10^{4.54} \mathrm{TCID}_{50} / \mathrm{mL}$.

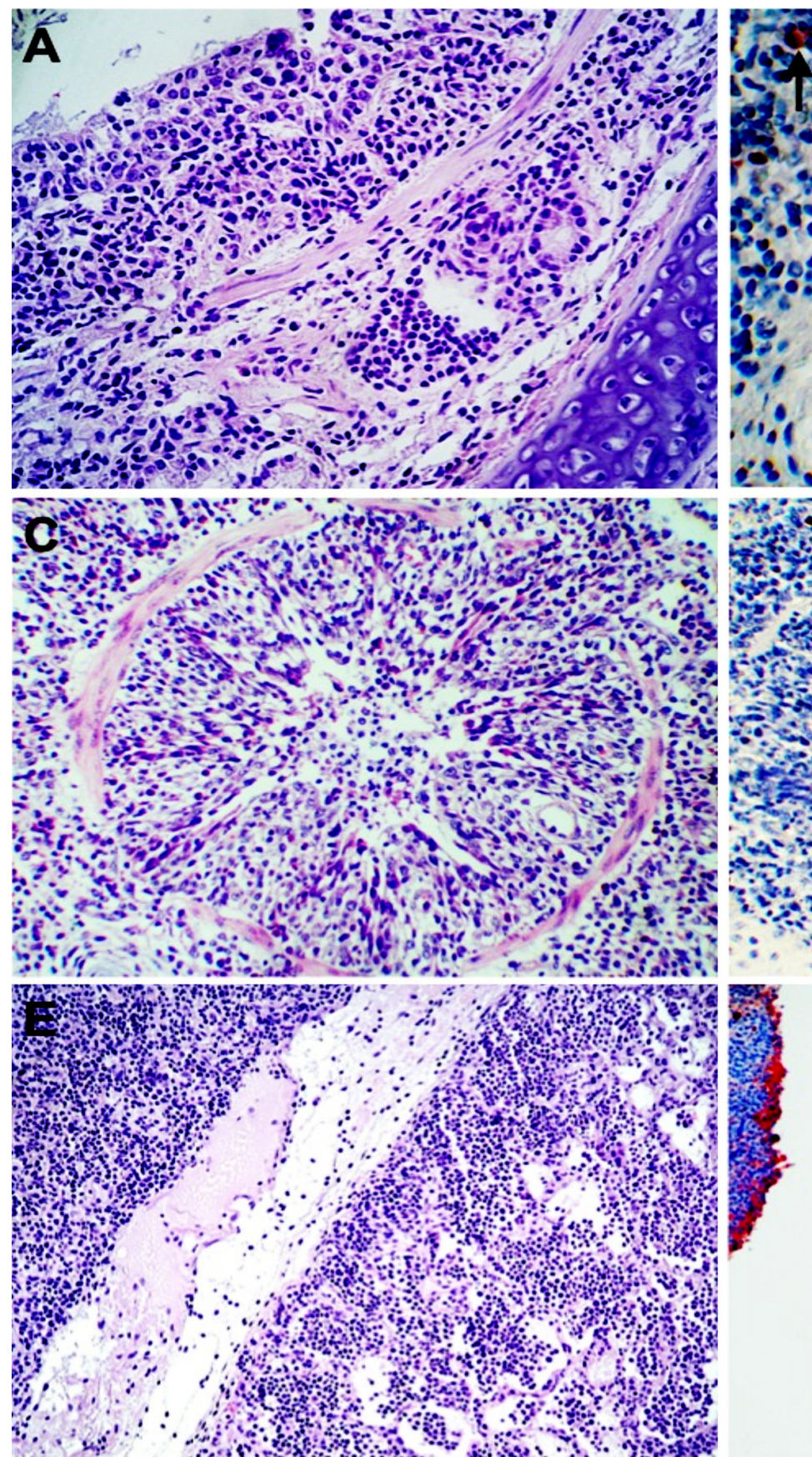

Table 2. Results of real time quantitative RT-PCR (qRT-PCR) and virus isolation for influenza $A$ virus detection in lung samples of pigs with respiratory clinical signs

\begin{tabular}{lccccc}
\hline \multicolumn{1}{c}{ Assay } & \multicolumn{2}{c}{ Negative } & & \multicolumn{2}{c}{ Positive } \\
\cline { 2 - 3 } \cline { 5 - 6 } & Number & $\%(95 \% \mathrm{CI})$ & & Number & $\%(95 \% \mathrm{CI})$ \\
\hline Virus isolation & 55 & $64.0(53.86-74.14)$ & & 31 & $36.0(25.86-46.14)$ \\
qRT-PCR & 50 & $58.1(47.67-68.53)$ & 36 & $41.9(31.5-52.3)$
\end{tabular}
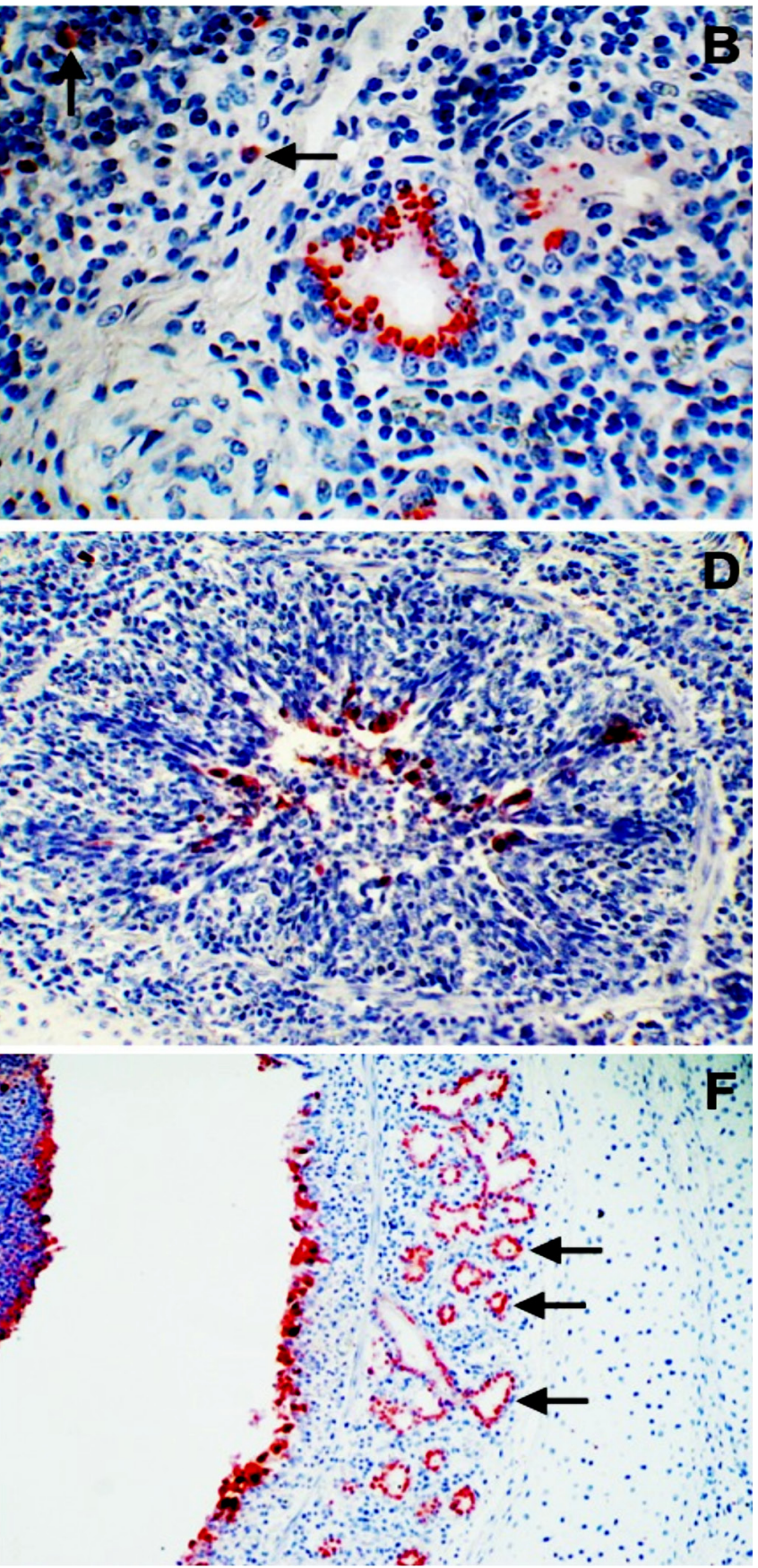

Fig.1. Swine lung histological lesions (A,C,E) and influenza A virus detection by immunohistochemistry (IHC; B,D,F). (A) Bronchial wall with neutrophil and lymphocyte infiltration in the mucosa and sub mucosa, mainly around bronchial glands. Hematoxylin and eosin (HE), 100x. (B) Red positive staining for viral nucleoprotein in the bronchiole epithelial cells cytoplasm, and scared in the cytoplasm of mononuclear cells (arrows). 200x. (C) Necrotizing bronchiolitis with sloughing of bronchiolar epithelium due to necrosis and lymphocytes infiltration in the lamina propria. HE, 100x. (D) Same area as C, stained by IHC showing intense staining of the remnant bronchiolar epithelium. 100x. (E) Intense neutrophilic infiltration in the alveolar lumen, associated to thickened interlobular septum due to edema and discrete lymphocytes infiltration. HE, 40x. (F) Intense red positive staining for influenza nucleoprotein in the bronchial glands (arrows), epithelium, and exudate in the bronchial lumen. 40x. 
Complete hemagglutinin (HA) and neuraminidase (NA) genes were sequenced and all were identified as of the H1N1 subtype (Rajão 2012, data not shown).

\section{Quantitative real time RT-PCR}

Nucleic acids of influenza A virus were detected in 36 samples by real time qRT-PCR (Table 2). DNA copy numbers in isolates ranged from $10^{1.22}$ to $10^{7.85}$, and the mean copy number was $10^{4.92}$. With serially diluted positive control DNA, the detection limits of the qRT-PCR assay was found to be $10^{1}$ copies DNA $\mu \mathrm{L}^{-1}$.

\section{Pathological examination of lungs}

The main macroscopic lesion observed was dark-red consolidation of cardiac, apical, and diaphragmatic lung lobes, with $30 \%$ to $70 \%$ impairment. Microscopically, the most common lesions were neutrophil, lymphocyte, or macrophage infiltration with different intensity, in the lumen of alveoli, bronchiole, and bronchi (46/60; 76.7\%); necrosis with bronchiolar epithelium sloughing and cellular debris in the lumen $(12 / 60 ; 20.0 \%)$; and alveolar $(15 / 60 ; 25.0 \%)$ or interlobular septal thickening $(13 / 60$; $21.7 \%$ ). Septal thickening was due to lymphocyte and histiocyte infiltration, and to lymphatic vessel dilation and edema in the interlobular septum. Congestion $(23 / 60$; $38.3 \%)$, hemorrhage $(5 / 60 ; 8.3 \%)$, and edema $(25 / 60$; $41.7 \%$ ) were also observed, as were mucus accumulation in the airways $(3 / 60 ; 5.0 \%)$ and bronchus-associated lymphoid tissue (BALT) hyperplasia $(14 / 60 ; 23.3 \%)$. Necrotizing bronchiolitis $(11 / 60 ; 16.7 \%)$ and neutrophilic bronchopneumonia $(43 / 60 ; 71.7 \%)$ were common diagnosis. Fibrinous to purulent pleuritis was observed in isolated cases $(3 / 60 ; 5.0 \%)$. Some lesions are shown in Figure 1 (A,C,E).

The results for influenza A nucleoprotein detection by IHC are shown in Table 3. Red staining was evident in the nucleus and cytoplasm of bronchi, bronchiole, and alveoli epithelium, but also in alveolar macrophages, and frequently in bronchial glands (Fig.1B,D,F).

\section{Table 3. Results of influenza A virus detection by immunohistochemistry (IHC) in lung samples of pigs with respiratory clinical signs}

\begin{tabular}{lcc}
\hline \multicolumn{1}{c}{ Result } & \multicolumn{2}{c}{ Affected } \\
\cline { 2 - 3 } & Number & Percentage (\%) \\
\hline IHC & 38 & 63.3 \\
Score I & 14 & 36.8 \\
Score II & 15 & 39.5 \\
Score III & 9 & 23.7
\end{tabular}

\section{DISCUSSION}

This study reports IAV detection and clinic-pathological characterization of influenza infection in pigs in six Brazilian states, indicating virus circulation in these regions. Thirty-six swine lung samples were positive by real time PCR, and 31 influenza viruses were isolated. Virus isolation has been previously performed in Brazil, but the isolated strains subtypes were not identified (Cunha et al. 1978, Mancini et al. 2006). Recently, pandemic H1N1 (pH1N1) influenza virus was identified in pigs in the south region of Brazil (Schaefer et al. 2011).

Viral nucleoprotein was detected in 38 lung samples by IHC, with nucleus or cytoplasm staining of bronchi and bronchioles epithelial cells, as reported previously (Vincent et al. 1997). The frequent staining of bronchial glands observed here is a common finding in human seasonal and pandemic influenza infection (Gill et al. 2010, Nakajima et al. 2012). Glandular staining was observed in pandemic H1N1 2009 virus infection in pigs (Sreta et al. 2009), however it is not usual in endemic infections (Vincent et al. 1997). Interestingly, receptors for human influenza viruses (NeuAc $\alpha 2,6 \mathrm{Gal}$ ) are found in mucous and serous glands of the pig's inferior respiratory tract (Nelli et al. 2010). We also detected positive staining in alveolar macrophages, as reported by Sreta et al. (2009). Influenza viruses can infect alveolar macrophages, but typically the infection is abortive and replication is not efficient (Rodgers \& Mims 1982, Yu et al. 2011).

Microscopic lesions observed in positive samples in the present study were similar to those reported for IAV infection in pigs, characterized by respiratory epithelium desquamation, with peribronchiolar and perivascular inflammatory infiltration (Richt et al. 2003, Jung et al. 2005, Sreta et al. 2009). Epithelial cells necrosis is also a common finding of IAV infection in pigs, accompanied by cellular debris and leucocytes deposition in the bronchiole lumen (Richt et al. 2003), which is similar to what we found. It is noteworthy to mention that in 29 (48.3\%) IHC-influenza positive lungs only alveoli and bronchiole neutrophilic and lymphocytic infiltrations were observed in lumen, with no necrotizing bronchiolitis. Considering these findings, IHC should be performed in routine diagnostics of neutrophilic bronchopneumonia cases even if no evident bronchiolitis is observed. Furthermore, an important lesion found in infected animals was fibrino-necrotic tracheitis (data not shown), probably resultant from trachea cell infection. It is well known that influenza virus can infect cells of both lower and upper respiratory tracts of pigs, but NeuAc $\alpha 2,6 \mathrm{Gal}$ receptors are more numerous in the upper tract (Nelli et al. 2010). Additionally, fatal cases of pandemic influenza in humans frequently result in necrotizing tracheobronchitis (Nakajima et al. 2012). Microscopic lesions observed in this study corroborate clinical findings observed in the studied herds, in which animals showed influenza-like acute mild to severe respiratory signs. Bacterial or PCV2 infection was detected in some herds where influenza virus infection was not confirmed (data not shown), suggesting that other pathogens may be responsible for the respiratory signs observed in those properties. Most animals infected with influenza virus were co-infected with some other pathogen. However, even though severe clinical signs and lesions are frequently observed in multiple infections with influenza virus (Choi et al, 2003), severe clinical signs were not frequent and microscopic lesions suggestive of secondary infection were observed only in rare cases in our study. Some macro and microscopic lesions found here are also common in other infections (e.g. Mycoplasma hyopneumoniae), such as BALT hyperplasia, which supports our observations of multiple infections. 
European countries and the United States producers routinely vaccinate their sows (Van Reeth 2007, Ma \&Richt 2010), but vaccines confer total protection only against homologous viruses (Poland et al. 2001, Kothalawala et al. 2006). However, vaccination against influenza virus is not performed in Brazil, and no commercial vaccines are available. Swine production increased development and housing in densely pig-populated areas, associated with the frequent introduction of novel viral strains makes swine influenza control more dependent on vaccination protocols (Vincent et al. 2008). We reported clinical influenza in nursery, grower, and finisher pigs in six different states in Brazil, which points to the lack of immune protection and elevated susceptibility of Brazilian swine. Thus, management and specific prevention measures are required to reduce viral dissemination and clinical impairment. Vaccination is an important tool for influenza prevention; nevertheless some factors need to be addressed before vaccination is considered in Brazil, such as the genetic characterization of influenza viruses circulating in swine herds, association of viral circulation and clinical illness, or the occurrence of other respiratory infection in the herds.

Influenza A virus circulation among pigs in various Brazilian states was confirmed in this study, resulting in respiratory disease outbreaks and causing production losses to producers. Even though there was evidence of influenza A virus circulation in pigs in Brazil before 2009 (Cunha et al. 1978, Brentano et al. 2002, Mancini et al. 2006, Rajão et al. 2012), the introduction of the pandemic H1N1 virus (Schaefer et al. 2011) appear to have led to more pronounced clinical signs, gross, and microscopic lesions in that species. Although influenza is a low mortality and fast recovery illness, the elevated morbidity leads to considerable economic impact due to the reduced food intake and consequential time increase to achieve slaughter weight (Fouchier et al. 2003). Thus, influenza presents a threat to the swine industry and it is essential to know its epidemiologic, clinical, and pathologic characteristics, so as to establish accurate diagnosis methods and develop efficient vaccines. Our results confirm the importance of influenza as a respiratory disease of Brazilian pigs and highlight the need to include it in the differential diagnosis during respiratory outbreaks and to consider preventive measures, such as vaccination, to protect Brazilian susceptible herds.

Acknowledgements.- To Dr. José Eustáquio Cavalcante for providing samples and Drs. Helen L. Del Puerto, Fabiana Alves, Fernanda G. Oliveira, and Gissandra F. Braz for technical support. This investigation was financed by Fundação de Amparo à Pesquisa do Estado de Minas Gerais (Fapemig), Conselho Nacional de Desenvolvimento Científico e Tecnológico (CNPq), INCT-Pecuária, and Pró-Reitoria de Pesquisa da UFMG. The authors DSR, JKPR, RMCG, ZIPL, and RCL are CNPq fellowship recipients.

\section{REFERENCES}

Alexander D.J. \& Brown I.H. 2000. Recent zoonosis caused by influenza A viruses. Rev. Sci. Tech. 19:197-225.

Brentano L., Ciacci-Zanella J.R., Mores N. \& Piffer I.A. 2002. Levantamento soroepidemiológico para Corona vírus Respiratório e da Gastroenterite Transmissível e dos Vírus de Influenza H3N2 E H1N1 em rebanhos suínos no Brasil. Comum. Téc. 306, Embrapa Suínos e Aves, Concórdia, p.1-6.
Caron L.F., Joineau M.E.G., Santin E., Richartz R.R.T.B., Patricio M.A.C. \& Soccol V.T. 2010. Sero prevalence of H3N2 influenza a virus in pigs from Paraná (South Brazil): Interference of the animal management and climatic conditions. Virus Rev. Res. 15:63-73.

Choi Y.K., Goyal S.M. \& Joo H.S. 2003. Retrospective analysis of etiologic agents associated with respiratory diseases in pigs. Can. Vet. J. 44:735737.

Cunha R.G., Vinha V.R. \& Passos W.D. 1978. Isolation of a strain of Мухоvirus influenzae-A suis from swine slaughtered in Rio de Janeiro. Revta Bras. Biol. 38:13-17.

Fouchier R.A.M., Osterhaus A.D.M.E. \& Brown I.H. 2003. Animal influenza virus surveillance. Vaccine 21:1754-1757.

Gill J.R., Sheng Z., Ely S.F., Guinee D.G., Beasley M.B., Suh J., Deshpande C., Mollura D.J., Morens D.M., Bray M., Travis W.D. \&Taubenberger J.K. 2010. Pulmonary pathologic findings of fatal 2009 pandemic influenza a/ h1n1 viral infections. Arch. Pathol. Lab. Med. 134:235-243.

Jung K., Ha Y. \& Chae C. 2005. Pathogenesis of swine influenza virus subtype H1N2 infection in pigs. J. Comp. Pathol. 132:179-184.

Killian M.L. 2008. Hemagglutination assay for the avian influenza virus, p.53-56. In: Spackman E. (Ed.), Avian Influenza Virus: Methods in molecular biology. Human Press, Totowa.

Koen J.S. 1919. A practical method for field diagnosis of swine diseases. Am. J. Vet. Med. 14:468-470. (Apud Zimmer \& Burke 2009)

Kothalawala H., Toussaint M.J. \& Gruys E. 2006. An overview of swine influenza. Vet. Quart. 28:46-53.

Luna L.G. 1968. Manual of Histologic Staining of the Armed Forces Institute of Pathology. $3^{\text {rd }}$ ed. McGraw-Hill, New York. 258p.

Ma W. \& Richt J. A. 2010. Swine influenza vaccines: current status and future perspectives. Anim. Health Res. Rev. 11:81-96.

Mancini D.A.P., Cunha E.M.S. \& Mendonça R.M.Z. 2006. Evidence of swine respiratory infection by influenza viruses in Brazil. Virus Rev. Res. 11:39-43.

Nakajima N., Sato Y., Katano H., Hasegawa H., Kumasaka T., Hata S., Tanaka S., Amano T., Kasai T., Chong J.M., Iizuka T., Nakazato I., Hino Y., Hamamatsu A., Horiguchi H., Tanaka T., Hasegawa A., Kanaya Y., Oku R., Oya T. \& Sata T. 2012. Histopathological and immune-histochemical findings of 20 autopsy cases with 2009 H1N1 virus infection. Mod. Pathol. 25:1-13.

Nelli R.K., Kuchipudi S.V., White G.A., Perez B.B., Dunham S.P. \& Chang K.C. 2010. Comparative distribution of human and avian type sialic acid influenza receptors in the pig. BMC Vet. Res. 6:1-9.

Palese P. \& Shaw M.L. 2007. Orthomyxoviridae: The viruses and their replication, p.1647-1689. In: Knipe D.M. \& Howley P.M. (Eds), Fields Virology. $5^{\text {th }}$ ed. Lippincott, Williams and Wilkins, Philadelphia.

Poland G.A., Rottinghaus S.T. \& Jacobson R.M. 2001. Influenza vaccines: A review and rationale for use in developed and underdeveloped countries. Vaccine 19:2216-2220.

Rajão D.S. 2012. Detecção e caracterização de isolados do vírus da influenza em suínos no Brasil. Tese de Doutorado, Universidade Federal de Minas Gerais, Belo Horizonte, MG. 90p.

Rajão D.S., Alves F., Del Puerto H.L., Braz G.F., Oliveira F.G., Ciacci-Zanella J.R., Schaefer R., Reis J.K.P., Guedes R.M.C., Lobato Z.I.P. \& Leite R.C. 2012. Serological evidence of swine influenza in Brazil.Influenza Other Respi. Viruses DOI: 10.1111/j.1750-2659.2012.00366.x

Reed L.J. \& Muench H. 1938. A simple method of estimating fifty percent endpoints. Am. J. Infect. Control 27:493-497.

Richt J.A., Lager K.M., Janke B.H., Woods R.D., Webster R.G. \& Webby R.J. 2003. Pathogenic and antigenic properties of phylogenetically distinct reassortant H3N2 swine influenza viruses cocirculating in the United States. J. Clin. Microbiol. 41:3198-3205.

Rodgers B.C. \& Mims C.A. 1982. Influenza virus replication in human alveolar macrophages. J. Med. Virol. 9:177-184.

Saunders S.E. \& Burke J.F. 1990. Rapid isolation of miniprep DNA for double strand sequencing. Nucleic Acids Res. 18:4948.

Schaefer R., Zanella J.R.C., Brentano L., Vincent A.L., Ritterbusch G.A., Silveira S., Caron L. \& Mores N. 2011. Isolation and characterization 
of a pandemic H1N1 influenza virus in pigs in Brazil. Pesq. Vet. Bras. 31:761-767.

Sreta D., Kedkovid R., Tuamsang S., Kitikoon P. \& Thanawongnuwech R. 2009. Pathogenesis of swine influenza virus (Thai isolates) in weanling pigs: An experimental trial. Virol. J. 6. DoI:10.1186/1743-422X-6-34.

Thacker E.L., Thacker B.J. \& Janke B.H. 2001. Interaction between Mycoplasma hyopneumoniae and Swine Influenza Virus. J. Clin. Microbiol. 39:2525-2530.

Van Reeth K. 2007. Avian and swine influenza viruses: Our current understanding of the zoonotic risk. Vet. Res. 38:243-260.

Vincent A.L., Ma W., Lager K.M., Janke B.H. \& Richt J.A. 2008. Swine Influenza Viruses: A North American perspective, p.127-154. In: Maramorosch K., Shatkin A.J. \& Murphy F.A. (Eds), Advances in Virus Research. Vol.72. Academic Press, Burlington.

Vincent L.L., Janke B.H., Paul P.S. \& Halbur P.G. 1997. A monoclonal-antibody-based immunohistochemical method for the detection of swine influenza virus in formalin-fixed, paraffin-embedded tissues. J. Vet. Diagn. Invest. 9:191-195.
Webster R.G., Laver W.G., Air G.M. \& Schild G.C. 1992. Molecular mechanisms of variation in influenza viruses. Nature 296:115-121.

Whelan J.A., Russell N.B. \& Whelan M.A. 2003. A method for the absolute quantification of cDNA using real-time PCR. J. Immunol. Methods 278:261-269.

WHO 2002. WHO Manual on Animal Influenza Diagnosis and Surveillance. $2^{\text {nd }}$ ed. World Health Organization, Geneva. 99p.

WHO 2009. CDC protocol of realtime RT-PCR for swine influenza A (H1N1). World Health Organization, Geneva. 8p.

Yoshida T., Shaw M.W., Young J.F. \& Compans R.W. 1981. Characterization of the RNA associated with influenza A cytoplasmic inclusions and the interaction of NS1 protein with RNA. Virology 110:87-97.

Yu W.C., Chan R.W., Wang J., Travanty E.A., Nicholls J.M., Peiris J.S., Mason R.J. \& Chan M.C. 2011. Viral replication and innate host responses in primary human alveolar epithelial cells and alveolar macrophages infected with Influenza H5N1 and H1N1 viruses. J. Virol. 85:6844-6855.

Zimmer S.M. \& Burke D.S. 2009. Historical Perspective: Emergence of Influenza A (H1N1) viruses. N. Engl. J. Med. 361:279-285. 